\title{
Disentangling conceptual antecedence for indigenous paradigm
}

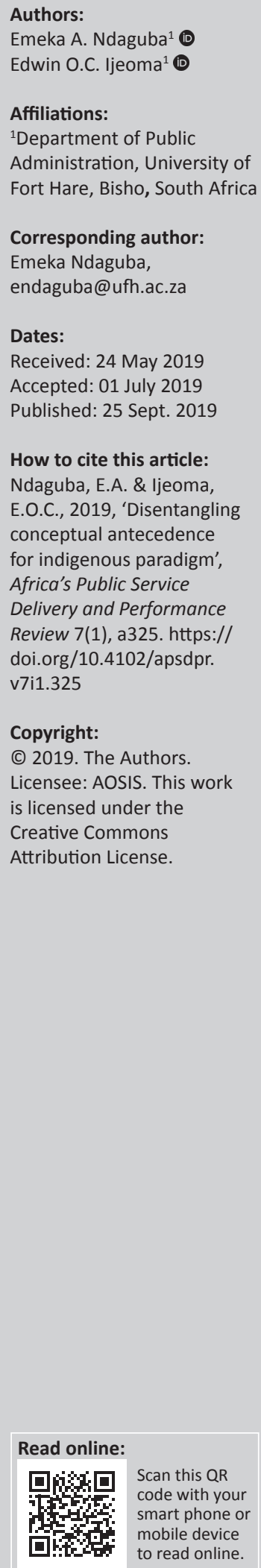

Background: This is the first in a series of articles seeking to provide an African perspective on the public administration discourse, especially regarding its development as a discipline. Theories and concepts utilised in the discipline within the African context to inform practice were largely borrowed. This field has gained from Western administrative thought, and the principles and culture of the West are applied in the development of the discipline.

Aim: This article explores the opportunities the Indigenous afford African Public Administration (IAPA) by critiquing the Western philosophical orientation of public administration to underscore Africa's influence on the development of the discipline.

Setting: The premise of this article is Africa, with public administration acting as a leverage for discussion.

Method: In gathering data for this article, the secondary source of data collection was explored, triangulation, Afrocentric perspective, and social constructivism were utilised. For the analysis, both narrative and theme analysis were employed.

Results: A key finding in this article is that scholarship in the community IAPA is both lacking and to some extent non-existent in the public administration discourse. The lack of understanding and documentation of Africa's institutions and administrative thoughts is prominent, thereby, creating a vacuum or knowledge gap in Africa's governance lexicon.

Conclusion: The essence of the indigenous public administration is to acknowledge the principles of indigenous African knowledge towards the growth and development of public administration as a discipline and be able to incorporate African principles like Ubuntu in the furtherance of public administration in praxis.

Keywords: Public administration; indigenous paradigm; decolonisation; community indigenous public administration; indigenous public administration.

\section{Introduction}

The philosophy of public administration in theory and praxis had evolved from disciplinary (Appleby 1947; Clapp 1948; Ndaguba \& Ijeoma 2017), interdisciplinary (Andrés-Gallego 2015), cross-disciplinary (Ndaguba \& Ijeoma 2017), multidisciplinary (Plsek \& Greenhalgh 2001) and recently transdisciplinary studies (McGregor 2004; Nicolescu 1997, 2014; Ndaguba \& Ijeoma 2017). The notions that the philosophy and paradigms of administrative thoughts have been transformational demonstrate the changing phases of development in this discipline (Pani 2010).

Research within this epistemic enclave of public administration facilitates changes in the practice of government functionaries (Lan \& Anders 2000). Although this discipline has birthed several others, such as governance, public management, development administration and studies, it lacks a unified theory for comprehending the phenomena. While some see governance as a theory within the study, others see it as a discipline in itself separate from the former.

Other approaches that may have developed into theory include public-private partnership, network governance, transparency, open government, integrity and outsourcing of government duties. However, there is no sufficient literature in publication to argue for a theory within this concept.

With the number of scholarly fora on the simplification of government functionaries, the lack of political and administrative will and corruption, debates have continued unabatedly to privatise government businesses. Thus, the rise or need for reinventing the current trends in public administration is expedient in rejuvenating various governmental systems on the African continent (Pani 2010). 
To reinvent the government, especially the governments in African countries, one has to be philosophical towards Africa's contribution to the body of knowledge in this discipline on the continent and elsewhere. More so, critical thought and attention must be given to reinventing the government on African terms with recourse to foreign policies, structures, frameworks and models, and not subservient to the Western philosophies.

This is because the structures, culture, environment, capability, capacity and intelligence, among others, differ significantly between the developed and developing nations. Hence, the more African administrative structure continues to adopt Western administrative practices, which are antithetical to the African culture, the more inefficiency and underproductivity is fuelled (Rodney 2018).

It is a truism that the more African countries continue to rely or lean on Western answers to African problems (Rodney 2018), the more debased, lazy, unfit for purpose and inconsequential African philosophers will be, to the extent that Africa's solutions to African problems may continue to linger (Ndaguba \& Okonkwo 2017).

Therefore, the purpose of this study is to question Africa's contribution to Western public administration practices, and seek to disentangle the conceptual antecedence for the need of an indigenous paradigm in this discipline. In this article, a narrative systematic review approach was utilised to collect data, and theme analysis was used for analysing material. Hence, the objective essentially is to review Africa's influence on the development of American public administration, as well as to introduce an ideology named Community Indigenous Public Administration Systems. The idea of Community Indigenous Public Administration Systems is to create awareness that indigenous self-determination, self-help and respect for diversity, and tolerance and value for indigenous cultures and religion are intricate in the development of a discipline. This is quintessential because without the understanding and proper harmonisation of the thoughts of communities, it will be impossible to achieve a community governance system that maybe impactful in addressing community quagmire and squabbles in African societies. Hence, a total devotion to Western procedures, processes, frameworks and approaches to solving Africa's problems is needed.

This article is divided into three sections: The first is related to the introduction and development of Western public administration as a field of study and practice. The second deals with the awakened spirit of African scholars on decolonisation and challenges the thought whether the West is in denial or agreement to African contribution towards the development of this discipline. The third section critiques the needs for Indigenous African Public Administration (IAPA) awakening in enhancing the efficiency and effectiveness of the government, as well as creating new thinking for understanding Africa's development.
However, the paradigms of public administration in the Western context take the centre stage.

\section{Paradigm 1: The politics and administration dichotomy 1900-1926}

The first phase of this discipline was to create a separate perspective to scholarship in political science, and demonstrate that public administration scholarship is not in conflict with or a duplication of political science. The study of Woodrow Wilson did help establish this notion in the late 19th century. The main concern of the new field of inquiry was to establish the locus of the discipline, where it fits in and what it should investigate (Pani 2010). Major credence would be given to the likes of Frederick Winslow Taylor, Frank J. Goodnow and Woodrow Wilson, among others, for setting the boundaries for the public administration. Goodnow (1904; 1910) identified two distinctive functions of a government: politics (the idea of expression or policies of the state will) and administration (has to do with the executive or implementation of the policies made by the politicians).

The view of Goodnow and other scholars was that the government bureaucracy is at the epicentre of the public administration. The leeway for public administration was created by the 1914 Committee at the instance of the Government of the American Political Science Association as a scientific discourse (Rosser 2013). In their statement, they argued that a political scientist deals with the training for citizenship and other professional preparations as law, and trains and prepares experts for political positions.

In the same vein, Leonard D. White (1891-1958) published a book on public administration. This was the first book that paid significant attention to public administration as a field of study; this work was a continuation of the arguments laid by Wilson, Stewart, Goodnow and several others at that time, titled Introduction to the Study of Public Administration. According to Waldo (1948), the book was quintessentially detailing the American character of public administration rather than giving a universal or broader view of administration. Hence, White's characteristics of public administration included: politics should be devoid from administration; management must lean decisions on scientific inquiry; public administration is capable of being a 'valuefree' science in its own merit; and the mission of administration is efficiency and economy. ${ }^{1}$

At the centre of this paradigm is to distinguish between politics and administration, hence the idea of the politics and administration dichotomy delinking value and fact dichotomy. The idea and notion of the value and fact dichotomy is premised on the argument that everything that public administrators perform or scrutinise in the executive

1.'Report of the Committee on Instruction in Government', Proceedings of the American Political Science Association, 1913-1914 (Washington, DC: APSA, 1914), p. 264 . 
branch of a government must be legitimate, factual and scientific (Henry 1975). Then, the notion of policy-making and related matters must be left to political scientists. After establishing a disparity or dichotomy between politics and administration, it was imperative to establish certain principles that public administrators must abide by (more or less a code of conduct), in order for administrators not to go beyond or interfere in politics and vice versa.

\section{Paradigm 2: The principles of administration 1927-1937}

After securing public administration as a discipline within the broad sphere of political science, it was quintessential to locate what the focus of the study would include, so that it does not interfere with the curriculum of its mother discipline, political science. To achieve this, some administrative principles were proposed in 1927 in the book titled, Principles of Public Administration written by F. W. Willoughby. It was the first book to pay full attention to public administration as a scientific inquiry, and it produced the principles of public administration.

Between 1930s and early 1940s, public administration placed itself within the managerial sphere of the public service (Henry 1975). In 1937, Luther Gulick and Lyndal Urwick's seminar paper pointed towards the principles of public administration- Science of Administration. It must be stated that these principles did not suffer setback or contestation, but no one can argue that science is far removed from real life, neither are social and management sciences are not sacrosanct and should never be sanctimonious (Gulick \& Urwick 2004).

The challenge that epitomised the era 1938-1950 included the inseparability of politics and administration in any remotely sensible fashion. The assumptions of the dichotomised politics and administration were questioned, resulting in the notion that a theory in public administration is applicable to political science, but not vice versa.

\section{Aliquoting the challenges}

One must understand that these four problems or challenges are not new, neither were they perceived for the purposes of this article. However, they existed during the foundation of this discipline, and certain contours are still prevalent in today's public administration praxis and theories. Both the first and second challenges were prevalent in Chester I. Barnard's book titled, The Functions of the Executive, and Herbert A. Simon's Administrative Behavior in 1938. The third challenge was noticed by Fritz Morstein Marx's in the Elements of Public Administration in 1946, and by John Merriman Gaus's assertion in the Trends in the Theory of Public Administration in 1950. Simon's Administrative Behavior argued that for every 'principle' of administration, there was a counter-principle to the first; this therefore made the principles of administration questionable.

\section{The reaction that ensued 1947-1950}

\section{Positives (on the part of public administration)}

In The Science of Public Administration, Herbert Simon argued for reinforcing components for public administrators as an alternative suggestion for the principles of administration (Pfiffner \& Presthus 1960). In the argument, Simon alluded that the pure science of public administration is a thorough grounding that may involve social psychology and public policy in resurrecting the field of political economy. In essence, public administrators must be a part of the normative political theory, typified in public policy, public management and the entire spectrum of humanity and human values to the polity (Hood 1995).

\section{Negative (on the part of political science)}

The idea of the generation of new knowledge was problematic, as a part, a sub-part or a miniature of a broader spectrum of knowledge. At the birth of public administration, political scientists resisted (still resist) the emergence of the independence of public administration as a field of inquiry. According to Caldwell (1968), rather than a call for knowledgeable action in the growing field of public administration, intellectualised understanding of the executive branch is appropriate. The image of student enrolments and government grants tends to favour public administrators (practitioners); this had and continues to affect the view of political scientists towards public administration scholars.

\section{Paradigm 3: Public administration as political science 1950-1970 (locus)}

The inadequacies in separating public administration from political science made philosophers or think tanks of administration consider public administration as a segment of political science. There are a growing number of issues at present, although chief among them is the fuzziness of the principles of administration by F.W. Willoughby, Luther Gulick and Lyndal Urwick among others (Shafritz et al. 2016).

Between 1950 and 1961, a linkage between public administration and political science was established, and public administration was synonymous to political science (Lowi 1964). At that time, public administration was more of an interest to political scientists than an area of knowledgeable action (Rehfuss 1973). Between 1961 and 1962, public administration became a discipline outside political science based on a report of the American Political Science Association (Denhardt \& Denhardt 2009).

Between 1964 and 1966, a survey conducted by political scientists demonstrated that the public administration review was gliding in prestige among them in relation to other journals (Ijeoma 2013), consequently signalling a decline in public administration faculties in America. In 1967, there was no evidence of public administration as a category in the programmes of the annual meeting of the American Political 
Science Association. In 1972, another survey suggested that merely $4 \%$ of articles published during a 10 -year period between 1960 and 1970 may be included in a category for bureaucratic politics; however, most research within this period maybe categorised more easily within the epistemic locale of public administration (Ijeoma 2013).

\section{Paradigm 4: Public administration as public administration 1956-1970 (focus)}

Understanding and appreciating the need for public administration to be understood and be seen as an epistemic domain of knowledgeable action resulted in the establishment of administrative science. A quarterly research journal was published on public, business and institutional administration; the essence of the journal was to publish and establish that administration is administration.

In the 1960s, the aftermath of the Second World War, the emergence of the United Nations after the fall of the League of Nations and the need for organisations to be structurally functional made public administration an interesting idea of organisational theories that will assist organisations and government organisations function effectively (Henry 1975).

To Keith M. Henderson and others, organisation development has its root as a speciality in administrative science, because of its involvement in opening up organisations, social psychology and the self-actualisation of its members (Henderson 2004). However, a conflict ensued between public administration and private (individual, group or business) administration as triggered by the administrative science discourse. To quell the dilemma, there was a need to clearly establish the boundaries of the public and private administration (Dosi, Nelson \& Winter 2001). Agreeably, the reason for the emergence of public administration was for the implementation of public (government) interest (Davis 1974).

\section{The emerging paradigm 5: Public administration as public administration 1970-?}

The disparity between what constituted public administration boundaries did not limit the disciplinary scholars. Scholars at this time were mainly represented as public affairs analysts. Since public affairs cover all matters that are either private or governmental in the public domain (Sharkansky 1972), this resulted in the expansion of the disciplinary boundaries to include policy science, policy-making process, agenda setting, evaluation of policy outcomes, political economy and administrative quagmires or maladministration.

\section{Institutionalising paradigm 5: Towards curricular autonomy}

Understanding the challenges that have bedevilled the discipline assisted the public administration discourse to stimulate intellectual discourses that are impactful to societies and relevant to reducing the bureaucratic menace and redtapism of the government. These prepared the discipline for an institutional autonomous educational curriculum, separate and distinct from political science and social psychology. It created an avenue for public administration to not just be seen as an administrative science, which is a combustor of business administration and other forms of administration. This may be because it launched a paradigmatic focus on management sciences and organisational theories, but mainly because it precisely stated its locus in relation to public affairs.

\section{The wake and the wave}

The discovery otherwise, identification of the locus and focus of the discipline (public administration) (Caldwell 1968; Henry 1975), awakened government employees to lean towards the discipline for knowledge among others. The growth in admission and registration in the public administration discipline demonstrates its influence in shaping the government in America (Dimmock \& Dimmock 1969; Nigro \& Nigro 1973). Between 1971 and 1973, the growth of enrolment in American Public Administration Studies escalated (between 1970 and 1971, the enrolment in undergraduate studies increased by $36 \%$ in public administration; and from 1971 to 1972, graduate enrolments in public administration were very high and increased by $50 \%$ (NASPAA 1972, 1974)). Programmes in graduate studies in public administration as a sub-discipline of the political science department reduced from $48 \%$ to $36 \%$ during this period. Programmes connected to and mainly concerned with business schools declined by 13\% (NASPAA 1972). The percentage of universities having a separate school or faculty for public administration doubled from $12 \%$ in 1971 to $25 \%$ in 1972 (NASPAA 1974). During this period, public administration accounted for over $23 \%$ of the 101 graduate programmes surveyed between 1971 and 1973. Between 1970 and 1972, within an 18-month period, the number of units relating to public administration became more than double to around 300 (NASPAA 1972:74). This situation and trajectory are still prevalent in Africa; in some African universities, the discipline of public administration is highly regarded as a sub-set of political science and not a cognate discipline (see Rhode University, South Africa), despite its contributions towards service delivery, innovation in government practices and government functionaries.

Considering the aforementioned reality of the discipline from an American perspective, one may argue that public administration has come of age to re-examine itself, trace its antecedents and collaborate with other realities from other continents and cultures in order to create a discipline that is time, motion, space, environment and people sensitive. Therefore, this article argues that having an African perspective on public administration is an indication of the growth and development of this discipline. 


\section{The West in denial or agreement}

Prevailing scholarships on Africa's administrative thoughts have two main orientations. The first group deals with the literature that denies the notion that Africa had no system of governance before contact with the West (Basheka 2015). According to Amaeshi and Yavuz (2008), it is very difficult, if not impossible, to identify and conceptualise the indigenous approaches and systems of administration or management in sub-Saharan African countries, particularly before European invasion. This argument is responsible for the Western rationale for both colonialism in Africa (with exception to Ethiopia) and apartheid (in South Africa).

The other school of thought demonstrates the high-tech and urbane nature of precolonial African administrative processes, approaches and systems (Basheka 2015), as exemplified in Egypt, Sudan and Ethiopia among others. Kottak (1994) ably argued that it was commonplace for the precolonial societies to establish varied forms of governance systems through fiefs, chiefdom and tribal politics. Inyang (2008) aptly concurs with the argument of Kottak and Basheka by stating that the destruction and erosion of administrative material and documents by the colonialists (see Egypt Library) was for the purposes of firstly denying the Africans the right to creation and knowledge, and secondly counterfeiting or replicating indigenous African management practices and theories in Africa for their home states. Counterfeiting the African initiative may not have gathered momentum in theoretical literature, but it is well established in storytelling or literatures in folklores; more so, Africans are aware of the consequence of the actions, which is today referred to as the consequence management. Inyang (2008) argues that the reason for the distortion was for Western management practices and theories to be considered as the driving force and panacea to the socio-economic quagmires experienced in the African continent. In essence, one may safely say that Western scholarship tends to devalue and disenfranchise the African literature, and distorts Africa's administrative progress along with the African civilisation, growth and development.

Boone (1995) argues that the African states have no organic linkage to the indigenous societies. This thought is premised on the epistemic violence that clouds Western literature during and post-colonial Africa. In that, the colonialists never took the issues relating to Africa's state formation into account. Nonetheless, there were certain elements and principles of statedom prevalent before Africa's fall to the West. Basheka (2015) stated this succinctly:

... one consequence of this analysis is that the issues of state formation has not been taken seriously, as many analysts tend to study the aggregate growth of the post-colonial state apparatus, or only describe similarities in the structure and processes of modern African governments, while effectively ignoring the social origins of cross-national differences in administrative practice and in the organizational configuration of state power. (p. 472)
While Western philosophers deny the existence of public administration in the precolonial era, evidence abound of households and individuals' falling short on law and the punishment thereafter (for instance, take the issues of twins and the consequence of stealing). In essence, the public administrators perform certain legitimate duties as designated by the chief, chief in council and kings among others. In fact, there is hardly any doubt to the legitimacy of or regulatory function in precolonial African societies. To Njoh (2006), the leadership during the precolonial era was much concerned about administering punishment, ensuring discipline and preserving the culture, customs and traditions of its people.

Recent theories and praxis in maladministration are clear evidence that punishment is a means of administering justice, including deterrence and compliance (Ndaguba et al. 2018c; Vyas-Doorgapersad \& Thombe 2013). The rise of consequence management on the African continent is another reminder of the fact that there were consequences for every negative action in precolonial Africa and reward for good deeds.

This is because the character of an organised and civilised society involves law and order, happiness and even distribution of wealth and an effective judicial and unbiased system of governance and administration. These attributes were engraved in the daily functionality of the African system and approach of governance or administration in the precolonial era. According to Mazrui (1986), the administration within the precolonial epoch was mainly decentralised and fragmented, while the highly centralised polities were fewer in numbers, which included, among others, the Songhai Empire, City or State of Benin (Benin Empire), Bakongo Kingdom, Ashanti Kingdom and Buganda Kingdom; these kingdoms were scattered around the West, the East and the Central Africa. This settles any score that the African societies throughout the history were unorganised.

\section{The need to understand the discourse - African Public Administration}

Several authors and commentators above have described public administration in diverse ways - an offspring or a sub-set of political science (Ndaguba \& Ijeoma 2017), a discourse in search of discipline and a process turned into a discipline, among others (Ndaguba \& Ijeoma 2017). One must understand that public administration or administration itself has been in existence since the primordial era, even in Africa. Nevertheless, what scholars have failed to do is to articulate the historical combustion of this discipline within the African context.

The French, German and American perspectives have dominated the African literature, which had turned the African perspectives into the issues of no importance. At a time when African problems require African solutions (Landsberg 2016; Ndaguba 2018), Western literatures are cited. 
The borrowed and implemented philosophies and frameworks in Africa are in most cases deemed unsuitable, largely due to the infrastructural issues, systemic issues, structural configuration, capacity and capability issues and misapplication of concepts and theories. Africans (the people referred to as Africans, inhibiting Africa as a continent white people, black people or brown people) have been in existence trading and investing even before the coinage of the concept African, Afrique or Africa. Therefore, there are certain principles that aided kings and queens (monarch system) at that time to govern their subjects effectively. Engaging in wars with other ethnic groupings and the construction of the Pyramids are some cases in point.

However, documentations of this noble gesture have remained contentious to the conspiracy theorists. As public administration is the process of governance (McKinney \& Howard 1998; Pommer \& Van Houwelingen 2016), to deny the Africans their rights, the invaders who also kidnapped the forebears, destroyed or, seized manuscripts and carted away experts from the continent.

To others, it deals with the non-functionality or functionality of government interventions, activities, programmes and projects (Appleby 1947; Clapp 1948; Kettl \& Fessler 2009; Rabin, Hildreth \& Miller 2007), according to Ndaguba and Ijeoma (2017:2), public administration is an academic enclave that deals with just about everything pertaining to governance and what government can influence.

If one presupposes that research themes in public administration follow practice rather than regulate practice (White 1986), one is left with more questions than answers, such as: Why was the African historical administrative prowess exempted from the discourse of the discipline? To what extent would an inclusion of the African Public Administration paradigm reduce the maladministration in Africa? As according to Gill and Meier (2000), research in public administration is much more evaluative than basic.

\section{The need for an indigenous paradigm}

The need for an indigenous public administration paradigm is imperative for quelling the misgivings and misapplication of Western and currently the Asian frameworks, models and theories on Africa (typified in the one-size-fit-all model) (Ndaguba \& Ijeoma 2018). Vyas-Doorgapersad (2011) argues that the African continent faces an incline in administrative crisis, which has resulted in several violent strike actions (Alexander 2010; Von Holdt 2010). This, to some extent, demonstrates the weakness of the borrowed administrative procedures, failed administrative processes, improper harmonisation of frameworks and programmes for intervention in African communities by the West.

The dwindling and poor image of public administration praxis (like corruption, state capture, maladministration, inadequate service delivery, etc.) on the African continent calls for a rethink of the functionality and orientation of the public service in Africa, especially within the purview of decolonisation (Ndaguba et al. 2018b, 2018c)

There are insinuations that before colonialism and the arrival of the West, Africa was a dark continent (Allen 2015; Oppong 2017), where disorderliness prevailed. However, several scholars have argued that such assumption is devoid of truth (Basheka 2015; Rodney 2018; Vyas-Doorgapersad 2011), because building a pyramid and a kingdom all over the African continent requires effective direction, experts' advice and the proper implementation of strategies and a resourceful leader. This largely demonstrates that a form of governance, orderliness and administration existed, although never properly documented by the Europeans that infiltrated and distorted the African mind set. As Basheka (2015) rightly argued:

The African continent has suffered a rather tormented history, following different historical epochs like shadows of colonialism, conquest, neo-colonialism, global capitalism and foisting upon the western organizational management/leadership practices. The indigenous systems of governance are so much neglected that they hardly receive the significant scholarly attention they deserve in most public administration write-ups and curricula in African universities. (p. 466).

African academicians and practitioners in the field of public administration would be considered to have failed their ancestors, if they fail to respond appropriately at a time when there is a higher need to vindicate our ancestors of their achievement who came before us. This can be done by establishing several administrative practices, which have now been sold back to the African states, such as good governance, open governance, network governance, anticorruption policies frameworks and theories, administrative law and practice in the discipline (Ndaguba \& Ijeoma 2018). One must recount the era of Sobukwe, Mandela and others at the University of Fort Hare, South Africa, where most of the liberation icons studied native administration, which maybe essential in unlocking their understandings to the working and activities of the government that preside over their collective future, thereby awakening their consciousness and liberating their minds. However, today such course and discourse are tagged racial and phased out.

The environment of the American or Western public administration paradigm does not take into cognizance the stages and development in other regions and nations of the globe. Hence, it could be argued that the Western system of public administration recommended systems that were largely in existence before their arrival back in Africa in the 20th century.

Scholars, leaders and managers focusing on the African continent must therefore explore newfangled prospects for addressing each nation's concerns for growth, development, poverty, nation building, peace building, inequality and social justice. In order to realise this purpose, professionals in the public service and academicians in academia must 
collaborate with civil societies and multinationals in building models for the growth and development of each community, due to their uniqueness and the failure of the one-size-fit-all model. As Herbert Simon stated earlier in the affirmation of the discipline, public administration is concerned with a stone that could not move unaided (Ndaguba \& Ijeoma 2017). The idea of public administration here is the combination of efforts to achieve what an individual, a community, a province or a nation may not achieve singlehandedly. In addition, in this scenario, it leans towards dealing with the collective efforts of the community members in solving a common communal problem that neither an individual nor household could resolve, if unassisted.

To realise this community indigenous public administration system, practitioners (government officials) of this venture must understand their collective and common history, their bargaining chip - comparative advantage, local economics, local politics, social and environmental laws, and be able to adapt and bridge multiple worldviews. While understanding the community indigenous public administration, it is also incumbent to understand the indigenous self-determination, self-help and respect for diversity, and tolerance and value for indigenous cultures and religions. This is quintessential because, without the understanding and proper harmonisation of the thought of communities, it might be impossible to achieve a community governance system that is impactful in addressing a community's quagmires and squabbles.

Other functions of the community indigenous public administration may include developing, analysing, implementing and evaluating the government programmes and projects by applying the cooperative and collaborative partnership systems in order to support or improve local economic growth and development. Analyse the current African legal and political frameworks to evaluate the public policies that may relate to the economic development. Formulate approaches to manage socio-political and economic challenges and decipher relevant opportunities specific to rural and remote communities to support the indigenous governance. Support natural resource stewardship in compliance with relevant statutes, while enhancing the ethical business practices and sustainability practices. Evaluate accounting and financial practices to support the governance and operations of the organisations in the local community. Develop and implement strategies to negotiate effectively with various levels of the government, and address the impact of diversity on an organisation's management planning in communities.

A key finding in this article is that scholarship in the community IAPA is both lacking and to some extent nonexistent in the public administration discourse. The lack of understanding and documentation of Africa's institutions and administrative thoughts is missing, thereby, creating a vacuum or knowledge gap in Africa's governance lexicon.
In conclusion, the essence of the indigenous public administration is to relate principles and practices of indigenous knowledge in the development of public administration as a discipline and provide indigenous knowledge on the contributions of African Public Administration towards the development and growth of the American Public Administration. The credence may be given to the level of epistemic violence in the Western ideologies on indigenous public administration development. In this context, if the administrative structures, processes, procedures and systems built in primordial African societies had been sustained, it would have enabled Africa to escape the fierce inadequacies witnessed on the continent. Therefore, the community IAPA framework is imperative, if the continent requires a model to revamp the calamity it inherited. Finally, at a time when decolonisation of the academic sector in Africa is gaining momentum, it is of the essence that philosophers within this epistemic enclave take the advantage to study and document the history of African Public Administration as a part of the broader decolonisation agenda.

\section{Acknowledgements}

The authors gratefully thank the anonymous reviewers for their assistance in shaping the research, as well as the section editor for his good advice on this research article.

\section{Competing interests}

The authors declare that they have no financial or personal relationships that may have inappropriately influenced them in writing this article.

\section{Authors' contributions}

E.A.N. wrote the manuscript. Supervision, direction and editing were done by E.O.C.I.

\section{Ethical consideration}

This article followed all ethical standards for carrying out research without direct contact with human or animal subjects.

\section{Funding information}

This research is sponsored by the Institute for Development Assistant Management, University of Fort Hare.

\section{Data availability statement}

Data sharing is not applicable to this article as no new data were created or analysed in this study.

\section{Disclaimer}

The views and opinions expressed in this article are those of the authors and do not necessarily reflect the official policy or position of any affiliated agency of the authors. 


\section{References}

Alexander, P., 2010, 'Rebellion of the poor: South Africa's service delivery protests A preliminary analysis', Review of African Political Economy 37(123), 25-40. https://doi.org/10.1080/03056241003637870

Allen, C., 2015, Tales from the Dark Continent: Images of British Colonial Africa in the twentieth century, Hachette, London.

Amaeshi, K. \& Yavuz, S., 2008, 'Untangling African indigenous management: Multiple influences on the success of SMEs in Kenya', Journal of World Business 43(3) 400-416.

Andrés-Gallego, J., 2015, 'Are humanism and mixed methods related? Leibniz's Universal (Chinese) dream', Journal of Mixed Methods Research 29(2), 118-132. https://doi.org/10.1177/1558689813515332

Appleby, P., 1947, 'Toward better public administration', Public Administration Review 7(2), 93-99. https://doi.org/10.2307/972751

Basheka, B.C., 2015, 'Indigenous Africa's governance architecture: A need for African public administration theory?', Journal of Public Administration 50(3), 466-484.

Boone, C., 1995, 'Rural interests and the making of modern African States', African Economic History 23(1), 1-36. https://doi.org/10.2307/3601724

Caldwell, L.K., 1968, 'Methodology in the theory of public administration', in J.C. Charlesworth (ed.), Theory and practice of public administration, Monograph 8, pp. 205-222, American Academy of Political and Social Science, Philadelphia, PA.

Clapp, G., 1948, 'Public administration in an advancing South', Public Administration Review 8(2), 169-75. https://doi.org/10.2307/972321

Davis, J.W. Jr., 1974, An introduction to public administration: Politics, policy, and bureaucracy, Free Press, New York.

Denhardt, R. \& Denhardt, J., 2009, Public administration: An action orientation, 6th edn., Thomson Wadsworth, Belmont, CA.

Dimmock, M.E. \& Dimmock, G.O., 1969, Public administration, 4th edn., Holt, Rinehart and Winston, New York.

Dosi, G., Nelson, R. \& Winter, S. (eds.), 2001, The nature and dynamics of organizational capabilities, Oxford University Press, Oxford.

Gill, J. \& Meier, K.J., 2000, 'Public administration research and practice: A methodological manifesto', Journal of Public Administration Research and Theory 10(1), 157-199. https://doi.org/10.1093/oxfordjournals.jpart.a024262

Goodnow, F.J., 1904, 'The work of the American political science association', Proceedings of the American Political Science Association 1, 35-46.

Goodnow, Frank. 1910. City Government in the United States. New York: Century Company.

Gulick, L. \& Urwick, L., 2004, Papers on the science of administration, Routledge, Abingdon, Oxon.

Henderson, K.M., 2004, 'Characterizing American public administration: The concep of administrative culture', International Journal of Public Sector Management 17(3), 234-250. https://doi.org/10.1108/09513550410530162

Henry, N., 1975, 'Paradigms of public administration', Public Administration Review 35(4), 378-386. https://doi.org/10.2307/974540

Hood, C., 1995, 'Emerging issues in public administration', Public Administration 73(1) 165-183. https://doi.org/10.1111/j.1467-9299.1995.tb00822.x

Ijeoma, E.O., 2013, South Africa's public administration in context, Verity, Pretoria.

Inyang, B.J., 2008, 'The challenges of evolving and developing management indigenous theories and practices in Africa', International Journal of Business and Management 3(12), 122-132. https://doi.org/10.5539/ijbm.v3n12p122

Kettl, D. \& Fessler, J., 2009, Summary of the politics of the administrative process, 7th edn., CQ Press. Washington, DC.

Kottak, C., 1994, Cultural anthropology, McGraw-Hill, New York.

Landsberg, C., 2016, 'African solutions for African problems: Quiet diplomacy and South Africa's diplomatic strategy towards Zimbabwe', Journal for Contemporary History 41(1), 126-148. https://doi.org/10.18820/24150509/jch.v41i1.7

Lan, Z. \& Anders, K.K., 2000, 'A paradigmatic view of contemporary public administration research: An empirical test', Administration \& Society 32(2), 138-165. https://doi. org/10.1177/00953990022019380

Lowi, T.J., 1964, 'American business, public policy, case-studies, and political theory' World Politics 16(4), 677-715. https://doi.org/10.2307/2009452

Mazrui, A., 1986, The Africans: A triple heritage, Little, Brown and Company, Boston, MA.

McGregor, S., 2004, 'The nature of transdisciplinary research and practice', viewed 19 October 2016, from https://www.kon.org/hswp/archive/transdiscipl.html.

McKinney, J.B. \& Howard, L.C., 1998, Public administration: Balancing power and accountability, ABC-CLIO, Westport.

NASPAA, 1974, Graduate school programs in public affairs and public administration, NASPAA, Washington, DC
National Association of Schools of Public Affairs and Administration (NASPAA), 1972, Public affairs and administration programs: 1971-72 survey report, NASPAA, Washington, DC

Ndaguba, E.A., 2018, 'Task on Tank model for funding peace operation in Africa: A Southern African perspective', Cogent Social Sciences 4(1), 1-20. https://doi.org/ 10.1080/23311886.2018.1484414

Ndaguba, E.A. \& ljeoma, E.O., 2017, 'Exploring the epistemology of transdisciplinarity in public policy and administration in South Africa', TD: The Journal for Transdisciplinary Research in Southern Africa 13(1), 1-13. a406. https://doi.org/ 10.4102/td.v13i1.406

Ndaguba, E.A. \& ljeoma, E.O.C., 2018, 'Digital open government in Africa: A strategy for bridging citizens' gap', Electronic Government, An International Journal 14(2), 115-133. https://doi.org/10.4102/td.v14i1.465

Ndaguba, E.A, Ijeoma, E.O.C., Nebo, G.I., Chungag, A.C. \& Ndaguba, J.D., 2018a, 'Assessing the effect of inadequate service provision on the quality of life of the poor: A focus on justice and education in Nigeria', Cogent Social Sciences 4(1), 1526437. https://doi.org/10.1080/23311886.2018.1526437

Ndaguba, E.A., Ndaguba, O.J., Tshiyoyo, M.M. \& Shai, K.B., 2018b, 'Rethinking corruption in contemporary African philosophy: Old wine cannot fit', TD: The Journal for Transdisciplinary Research in Southern Africa 14(1), 1-10. https://doi. org/10.4102/td.v14i1.465

Ndaguba, E.A., Nzewi, O.I., ljeoma, E.C., Sambumbu, M. \& Sibanda, M.M., 2018c 'Using Taylorism to make work easier: A work procedure perspective', South African Journal of Economic and Management Sciences 21(1), 1-10. https://doi. org/10.4102/sajems.v21i1.2120

Ndaguba, E.A. \& Okonkwo, C., 2017, 'Feasibility of funding peace operation in Africa: Understanding the challenges of Southern African development community
standby force (SADCSF)', Africa Review 9(2), 140-153. https://doi.org/10.1080/09 standby force (SADCSF)',
744053.2017.1329807

Nicolescu, B., 2014, 'Methodology of transdisciplinarity', World Futures 70(3-4), 186-199.

Nicolescu, B., 1997, 'The transdisciplinary evolution of the university condition for sustainable development', CIRET, paper presented at the International Congress of the International Association of Universities, Chulalongkorn University, Bangkok, Thailand, viewed 27 March 2019, from https://ciret-transdisciplinarity. org/bulletin/b12c8.php.

Nigro, F.A. \& Nigro, L.G., 1973, Modern public administration, 3rd edn., Harper and Row, New York.

Njoh, J.A., 2006, Tradition, culture and development in Africa: Historical lessons for modern development planning, Ashgate Publishing, Surrey, FL.

Oppong, N.Y., 2017, 'Still the dark continent? Towards contextual methodological approaches to management development research in foreign multinational firms in Africa', International Journal of Cross Cultural Management 17(2), 237-256. https://doi.org/10.1177/1470595817706384

Pani, N., 2010, 'Research in public administration through ages', The Indian Journal of Political Science 71(4), 1293-1309.

Pfiffner, J.M. \& Presthus, R., 1960, Public administration, 5th edn., Ronald, New York.

Plsek, P.E. \& Greenhalgh, T., 2001, 'Complexity science', British Medical Journa 323(7313), 625-628. https://doi.org/10.1136/bmj.323.7313.625

Pommer, E. \& Van Houwelingen, P., 2016, 'Public administration in Europe', Zarzqdzanie Publiczne 2(36), 34-53. https://doi.org/10.15678/ZP.2016.36.2.02

Rabin, J., Hildreth, W.B. \& Miller, G.J., 2007, Handbook of public administration, 3rd edn., Routledge, New York, NY.

Rehfuss, J., 1973, Public administration as political process, Charles Scribner's Sons, New York.

Rodney, W., 2018, How Europe underdeveloped Africa, Verso Trade, Brooklyn, NY.

Rosser, C., 2013, 'Examining Frank J. Goodnow's Hegelian heritage: A contribution to understanding progressive administrative theory', Administration \& Society 45(9), 1063-1094.

Shafritz, J.M., Borick, C., Russell, E.W. \& Hyde, A.C., 2016, Introducing public administration, Routledge, London.

Sharkansky, I., 1972, Public administration: Policy-making in government agencies, 2nd edn., Markham, Chicago, IL.

Von Holdt, K., 2010, 'Institutionalisation, strike violence and local moral orders', Transformation: Critical Perspectives on Southern Africa 72(1), 127-151. https:// doi.org/10.1353/trn.0.0063

Vyas-Doorgapersad, S., 2011, 'Paradigm shift from new public administration to new public management: Theory and practice in Africa', TD: The Journal for Transdisciplinary Research in Southern Africa 7(2), 235-250.

Vyas-Doorgapersad, S. \& Thombe, L.M., 2013, 'Chapter 2: Training civil servants in the democratic Republic of Congo', in P. Haruna \& S. Vyas-Doorgapersad (eds.), Public administration training in Africa, pp. 27-40, CRC Press, Boca Raton, FL.

Waldo, D., 1948, The administrative state, Ronald, New York.

White, J.D., 1986, 'On the growth of knowledge in public administration', Public Administration Review 46(1), 15-24. https://doi.org/10.2307/975438 